\title{
INFLUENCE OF BIOLOGICAL PRODUCTS ON THE GROWTH AND QUALITATIVE CHARACTERISTICS OF SWEET BASIL (OCIMUM BASILICUM L.)
}

Sonata KAZLAUSKAITE், Institute of Biology and Plant Biotechnology, Faculty of Agronomy, Aleksandras Stulginskis University, Studentu g. 11, LT-53361 Akademija, Kauno r., Lithuania; sonata.kazlauskaite@ asu.lt (corresponding author)

Audroné ŽEBRAUSKIENĖ, Institute of Agricultural and Food Sciences, Faculty of Agronomy, Aleksandras Stulginskis University, Studentų g. 11, LT-53361 Akademija, Kauno r., Lithuania; audrone.zebrauskiene@asu.lt

Povilas MULERČIKAS, Institute of Biology and Plant Biotechnology, Faculty of Agronomy, Aleksandras Stulginskis University, Studentų g. 11, LT-53361 Akademija, Kauno r., Lithuania; povilas.mulercikas@asu.lt

Ilona VAGUSEVIČIENÉ, Institute of Agricultural and Food Sciences, Faculty of Agronomy, Aleksandras Stulginskis University, Studentų g. 11, LT-53361 Akademija, Kauno r., Lithuania; ilona.vaguseviciene@ asu.lt

Elena SURVILIENĖ, Laboratory of Plant Protection, Institute of Horticulture, Lithuanian Research Centre for Agriculture and Forestry, Kauno g. 30, LT-54333 Babtai, Kauno r., Lithuania; e.surviliene@1sdi.lt

Aurimas KRASAUSKAS, Institute of Biology and Plant Biotechnology, Faculty of Agronomy, Aleksandras Stulginskis University, Studentų g. 11, LT-53361 Akademija, Kauno r., Lithuania; aurimas.krasauskas@asu.lt

Investigation of impact of novel plant origin products on sweet basil has been carried out in 2014-2015. The plants were grown in the poly tunnel. The test on sweet basil quality parameters was carried out in the Laboratory of the Quality of Plant Raw Materials at Aleksandras Stulginskis University applying standardized analysis methods. It has been determined that, the sweet basil comparing with the control grew best in both $2014(80.1 \mathrm{~cm})$ and $2015(80.8 \mathrm{~cm})$ when biological products Canelys, Ekoflavon and Ekoflavon + Oleorgan were applied. In 2014, the most significant absolute dry matter content (92.20\%) was accumulated using Oleorgan, and in 2015, significantly the highest dry matter content (90.19\%) has been accumulated using Ecoflavon + Canelys. The most significant (11.64\%) crude fibre content in 2014 has been obtained under Canelys application, while in 2015, significantly the highest result $(14.26 \%)$ has been collected by the control. Significantly the highest quantity of crude ash $(19.44 \%)$ in 2014 has been determined when the plants were treated with Canelys, however in 2015 , the best result $(21.86 \%)$ has been obtained after the use of the Oleorgan. The most significant $(20.07 \%$ ) crude protein content in 2014 has been accumulated when the plants were treated with Ekoflavon. Therefore, in 2015 significantly the highest $(16.68 \%)$ crude protein content was found in the treatment Ekoflavon + Canelys, still the result did not differ significantly from the treatment when only Ecoflavon was used.

The aim of the study was to investigate the influence of some biological products on the growth and qualitative characteristics of sweet basil.

Keywords: biological products, sweet basil, Canelys, Oleorgan, Ekoflavon.

\section{INTRODUCTION}

Spice, aromatic and medicinal plants are an important source of natural substances. The assortment and production volumes of natural additives, supplements and other biologically active preparations are growing rapidly over the world (Marotti et al, 1996; Kruger et al, 2002; Vina, Murillo, 2003). Sweet basil (Ocimum basilicum L.) is widely grown as a spice and medicinal plant in Western European countries, Asia, Africa and America (Simon et al, 1999; Meyers, 2003; Jayasinghe et al, 2003; Labra et al, 2004; Ismail, 2006; Telci et al, 2006). Due to its beneficial curative, aromatic, nutritional properties, sweet basil is increasingly grown in Lithuania (Ragažinskienė et al, 2005; Ruzgienè, Mackevičius, 2010; Obelevičius et al, 2011; Gudžinskas et al, 2013). Basil contains some amounts of essential oils, terpenes, polyphenols, glycosides, flavonoids, vitamins C, P, carotenoids, saponins and sugars (Tateo, 1989; Sengul, Sezen, 2000; Keita et al, 2001; Ozcan, Chalchat, 2002; Burt, 2004; Lee et al, 2005; Gülëin et al, 2007; Maročkienè et al, 2012; Rajesh, Joshi, 2014). Sweet basil growers confront with dangerous diseases: fusariosis, rot, downy mildew (Garibaldi et al, 1997; Zhang, Roberts, 2009; Grigaliūnaitè, 2001; Tran, 2011; Wyenandt et al, 2015). These plants are attacked by spider mites, aphids (Meyers, 2003; Johnny's Selected Seeds, 2015). Against the harmful organisms, the main pest management method is a treatment by chemical plant protection products, however cultivating spice or medicinal plants this way is unacceptable. Increasingly, biological products are used for improvement of plant physiological processes, for promotion of soil biological processes, and augmentation of plant productivity. It has been noticed that after the treatment with biological product solutions, the plants grow and develop more intensively, they form faster the

Copyright (C) 2017 The Authors. Published by Aleksandras Stulginskis University. This is an open-access article distributed under the terms of the Creative Commons Attribution License (CC-BY 4.0), which permits unrestricted use, distribution, and reproduction in any medium, provided the original author and source are credited. 
maximum leaf assimilation area, the process of photosynthesis becomes more intensive, assimilates are transported from leaves to roots more rapidly and plant productivity increased (Novickienė, 1994; Hussein et al, 2006; Jakienė, 2011).

Since sweet basil is grown and used as a medicinal herb and spice, any synthetic products are undesirable for the care of these plants; therefore, the application of natural products might solve many problems of maintenance.

The aim of the research was to investigate the influence of applied biological products on sweet basil (Ocimum basilicum L.) growth and some qualitative characteristics.

\section{METHODS}

Investigation of impact of novel plant origin products Canelys, Oleorgan and Ekoflavon on sweet basil $(O$. basilicum L.) has been carried out in 2014-2015.

Sweet basil seeds were sown on $1^{\text {st }}-3^{\text {rd }}$ of April. Seedlings were grown in Durpeta peat substrate, in 0.51 of volume plastic pots for $4-5$ weeks. The seedlings were transplanted in a poly tunnel on $5^{\text {th }}-10^{\text {th }}$ of May at an intervals of $20 \times 40$ $\mathrm{cm}$ into the soil. Agrochemical analyses of the soil were performed in the Laboratory of the Quality of Plant Raw Materials at Aleksandras Stulginskis University applying standardized analysis methods: phosphorus $\left(\mathrm{P}_{2} \mathrm{O}_{5}\right) 706.32 \mathrm{mg} \mathrm{kg}^{-1}$, potassium $\left(\mathrm{K}_{2} \mathrm{O}\right) 1132.8 \mathrm{mg} \mathrm{kg}^{-1}$, nitrogen $(\mathrm{N}) 0.3468 \mathrm{mg} \mathrm{kg}^{-1}, \mathrm{pH} 6.72$.

Plant irrigation and ventilation were carried out as needed, maintaining an ambient temperature of $25-28^{\circ} \mathrm{C}$ and a relative humidity of $80 \%$.

The research was carried out in five replications according to the experiment scheme:

1. Control (no spraying bioproducts, pure water only);

2. Oleorgan (Azadirachta indica seed oil soap $40 \%$, organic matter $40 \%$ ) spraying $0.3 \%$ solution;

3. Canelys (Cinnamonum sp. leaf and bark extract $70 \%$, organic matter $60 \%$ ) spraying $0.3 \%$ solution;

4. Ekoflavon (a complex of bioflavonoids and excipients) spraying $0.025 \%$ solution;

5. Ekoflavon $0.025 \%$ + Oleorgan spraying $0.3 \%$ solutions mixture;

6. Ekoflavon $0.025 \%$ + Canelys spraying $0.3 \%$ solutions mixture.

The plants were sprayed with biological products once a week. The height of sweet basil were performed every fourteen days. The raw material of the basil was harvested early in August and was naturally dried, in a place protected from direct sunlight. The test on sweet basil quality parameters was carried out in the Laboratory of the Quality of Plant Raw Materials at Aleksandras Stulginskis University. Absolute dry matter content, crude fibre content, crude ash, and crude protein content were determined applying standardized analysis methods:

- dry matter content was defined by drying the sample to constant weight at $105^{\circ} \mathrm{C}$ (LST ISO 751:2000);

- crude fibre content was evaluated by intermediate filtration method (Januškevičius, Mikulionienė, 2004);

- crude protein content was determined by the Kjeldahl method (LST 1532:1998);

- the content of crude ash (mineral matter) was defined by burning samples in dry method (Januškevičius, Mikulionienė, 2004).

The results of the research were processed applying the dispersion analysis method by the computer program DISVEG from the statistical data processing package "Selekcija" (Tarakanovas, Raudonius, 2003).

\section{RESULTS}

Measurements sweet basil height revealed that the highest plants grew up in 2014 when Canelys was applied (80.1 $\mathrm{cm})$. However, this parameter was not significantly different from the control and from the treatments where Ecoflavon and mixture of Ekoflavon + Oleorgan were used. Significantly lowest average plant height $(62.2 \mathrm{~cm})$ was recorded after treatment of a mixture of Ekoflavon + Canelys.

In 2015, the highest plants $(80.8 \mathrm{~cm})$ were observed in the treatment with Ecoflavon, nevertheless, the result did not differ significantly from treatments where Canelys and mixture of Ekoflavon + Oleorgan were used. On average, the lowest $(70.0 \mathrm{~cm})$ basil grew up after spraying by Oleorgan. Here, the average height of the plants was not significantly different from the average height of plants treated with Canelys, mixture Ekoflavon + Canelys and control (Fig. 1).

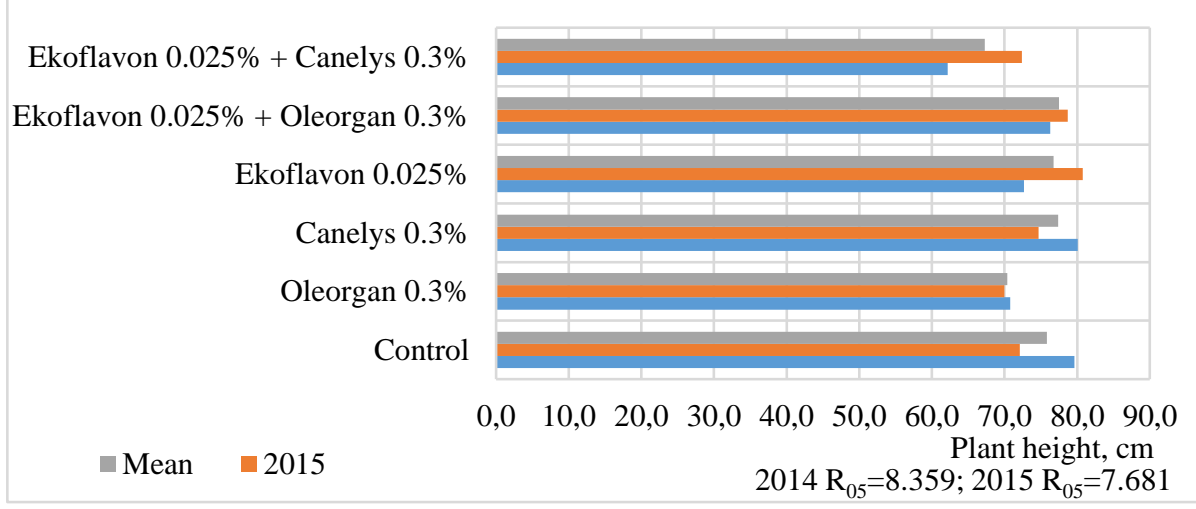

Figure 1 . The average height of the $O$. basilicum L. treated with different biological products, 2014-2015. 
In 2014, the highest significant dry matter content of $92.20 \%$ was determined in sweet basil after Oleorgan usage. Therefore, the lowest amount of $91.14 \%$ of dry matter content was accumulated in the treatment where mixture of Ekoflavon + Oleorgan was applied. $91.92 \%$ of dry matter were found after Ekoflavon treatment, and this result was significantly different from those in which the basil was treated with a Canelys, mixture of Ekoflavon + Canelys, and in control.

In 2015 the highest significant content of dry matter (90.19\%) was accumulated by spraying plants with mixture Ekoflavon + Canelys. There were no significant differences in other treatments of the experiment (Fig. 2).

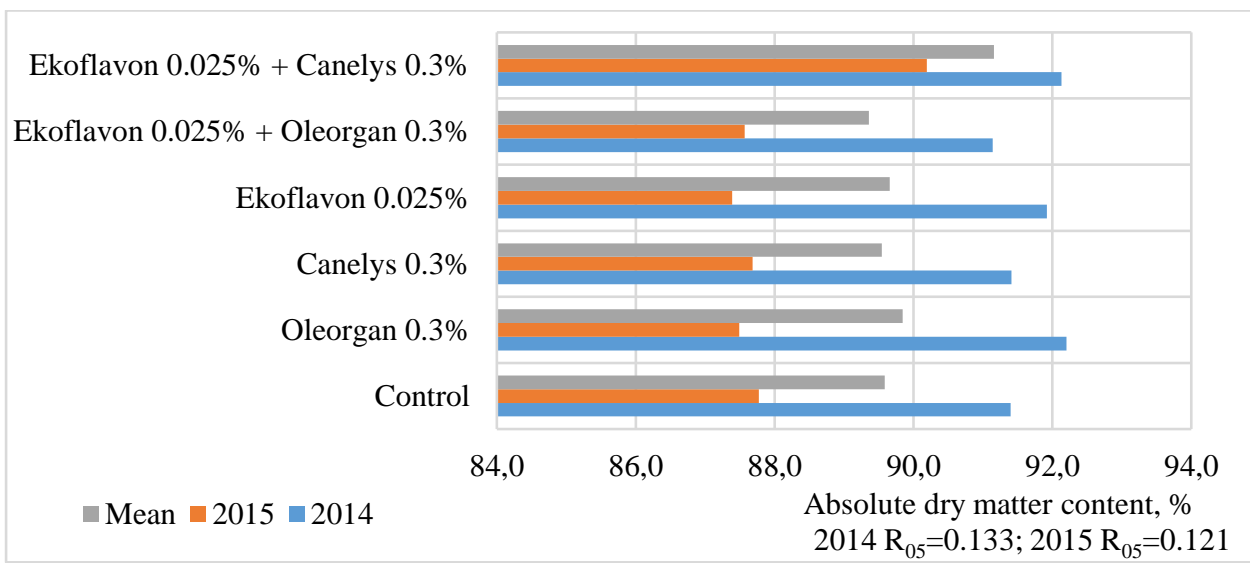

Figure 2. Absolute dry matter content in O. basilicum L. treated with different biological products, 2014-2015.

The most significant crude fibre content (11.64\%) was detected in 2014 after application of Canelys. A similar crude fibre content (10.36-11.4\%) was found in the plants treated with other biological products and did not differ significantly from the control variant, where the plants accumulated $10.72 \%$ of crude fibre. An exception was treatment with Oleorgan, where the crude fibre content reached $9.58 \%$.

In 2015, significantly the highest crude fibre content was determined in the control. Comparing crude fibre content detected in sweet basil raw materials treated with different biological products, it is possible to state that the highest crude fibre content (13.44\%) was accumulated applying the mixture of Ekoflavon + Oleorgan. Therefore, the result did not differ significantly from other treatments (Fig. 3).

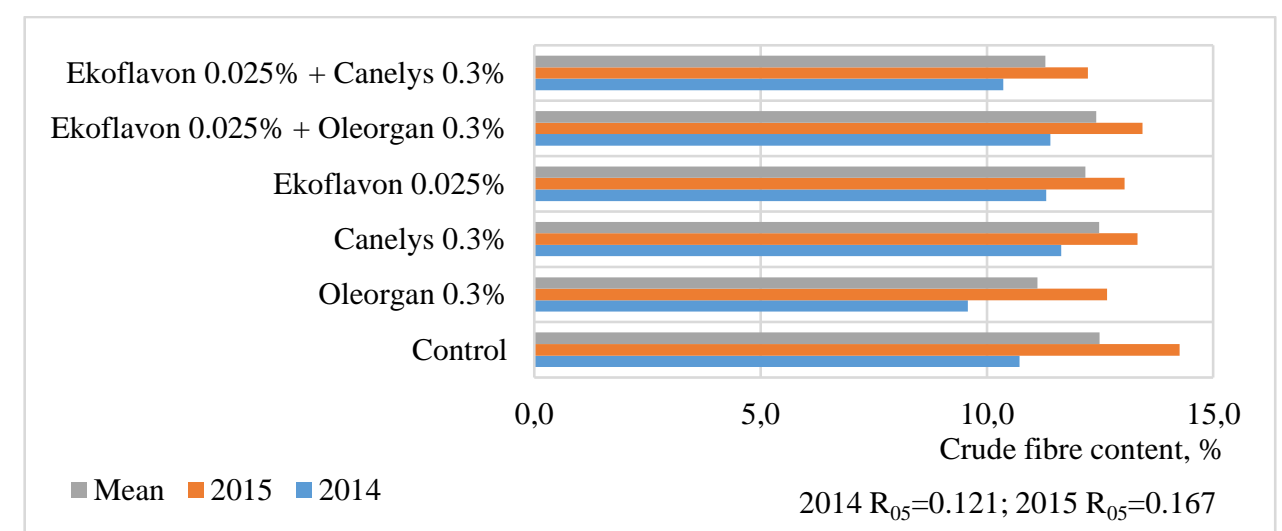

Figure 3. Crude fibre content in $O$. basilicum L. treated with different biological products, 2014-2015.

In 2014, the highest significant content of crude ash (19.44\%) was accumulated in plants after treatment with Canelys. Meanwhile, in 2015, the best result has been received applying Oleorgan (21.86\%). The lowest content of crude ash was defined after Ekoflavon and mixture of Ekoflavon + Canelys application on sweet basil plants in 2014. Whereas, in 2015, crude ash content has been detected very similar in all treatments of the experiment and any significant difference has not been determined (Fig. 4).

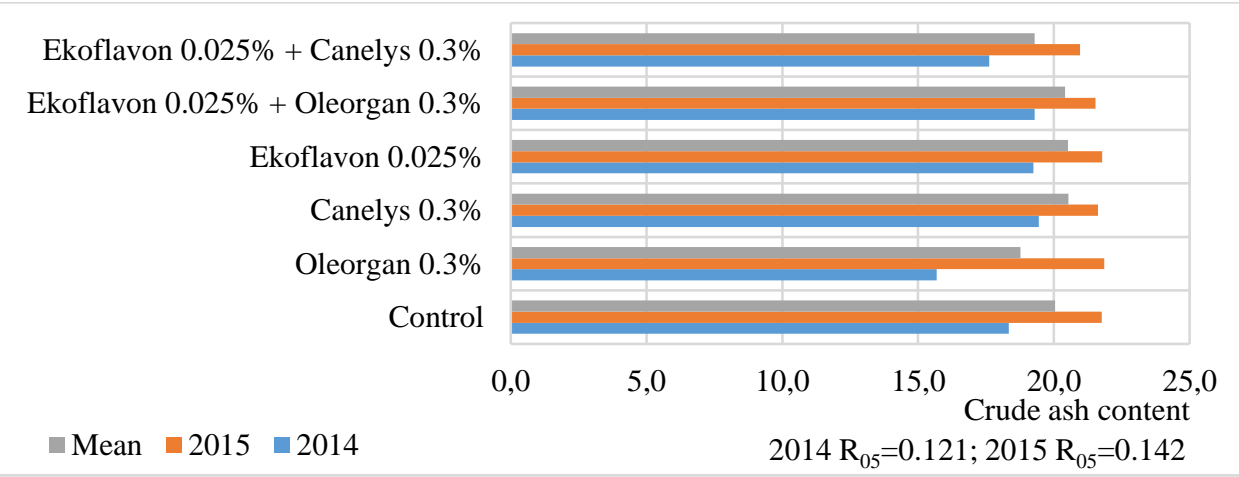

Figure 4. The content of crude ash from $O$. basilicum L. treated with different biological products, 2014-2015. 
The content of crude proteins accumulated in raw material of sweet basil treated with different biological products is presented in Figure 5. The highest significant content of crude proteins (20.07\%) in the absolute dry matter of sweet basil was determined in the treatment where Ekoflavon was applied in 2014. Comparing the effectiveness of the used biological products, it is possible to state that the application of Ekoflavon + Canelys mixture gave very close result, and the crude protein content reached $19.42 \%$. The least significant content of crude proteins was accumulated by plants without any application (13.63\%) and after Oleorgan treatment $(15.11 \%)$.

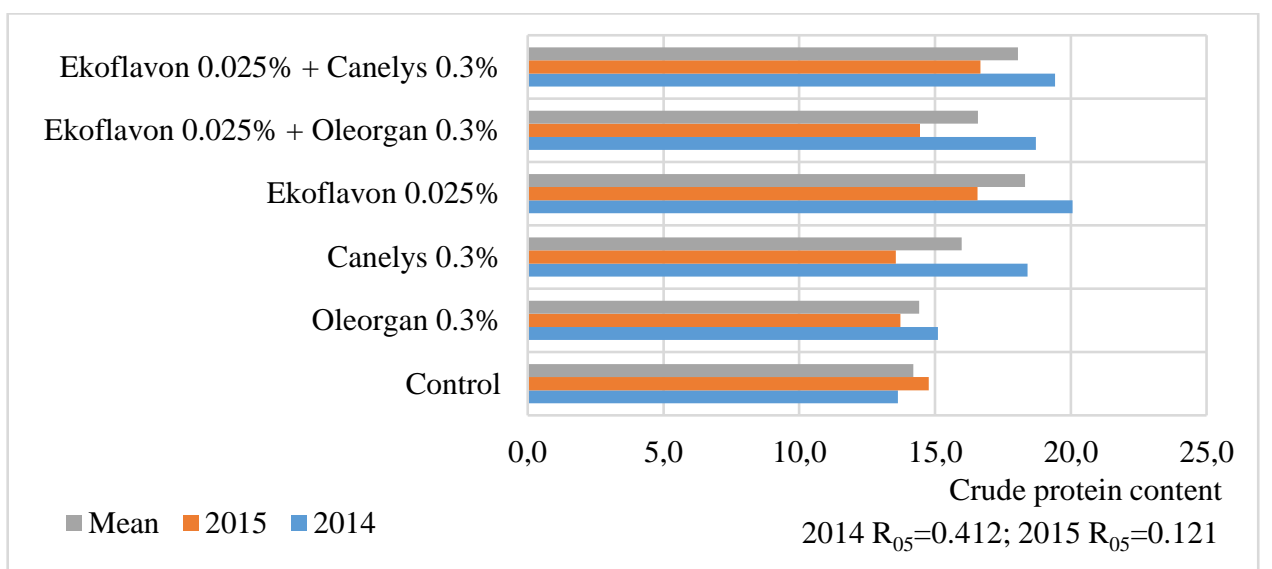

Figure 5. Crude protein content in O. basilicum L. treated with different biological products, 2014-2015.

In 2015, the highest significant content of crude proteins was obtained when plants were treated by mixture Ecoflavon + Canelys (16.68\%). Sweet basil treatment by Ekoflavon gave similar result in accumulated content of crude proteins as well (16.57\%). Nevertheless, there was no significant difference among results. Application of Canelys was not successful enough in accumulation of proteins in sweet basil comparing with other treatments of the experiment. Plants after Canelys application accumulated the lowest significant crude protein content (13.55\%).

\section{CONCLUSIONS}

1. Sweet basil (Ocimum basilicum L.) grew the most intensively under regular application of biological products Canelys, Ekoflavon and mixture of Ekoflavon + Oleorgan.

2. The highest significant absolute dry matter content in sweet basil was accumulated by the treatment of Oleorgan and mixture of Ekoflavon + Canelys.

3. The highest significant crude fibre content in sweet basil was reached applying Canelys.

4. Regular application of Canelys, Oleorgan and Ekoflavon resulted in the highest significant content of crude ash in sweet basil.

5. Regular treatment of sweet basil by Ekoflavon and mixture of Ekoflavon + Canelys influenced on accumulation of the significantly highest content of crude proteins.

\section{REFERENCES}

1. Burt, S. 2004. Essential oils: their antibacterial properties and potential applications in foods-a review. International Journal of Food Microbiology, Vol. 94, pp. 223-253. https://doi.org/10.1016/j.ijfoodmicro.2004.03.022

2. Garibaldi, A., Gullino, L., Minuto, G. 1997. Diseases of Basil and Their Management. Plant Disease, Vol. 81, 2, pp. 125-128. https://doi.org/10.1094/PDIS.1997.81.2.124

3. Grigaliūnaite, B. 2001. Fungi of the genus Botrytis P. Micheli:Pers. Plants in Lithuania. Biologija, No. 3, pp. 14-17.

4. Gudžinskas, Z., Burneckienė, I., Malciūtè, A., Mikaliūnaitė, R. 2013. Garden, garden, flower bed. Vilnius, pp. $292-295$. [InLithuanian]

5. Gülēin, I., Elmastat, M., Hassan, Y. Aboul-Enein. 2007. Determination of Antioxidant and Radical Scavenging Activity of Basil (Ocimum basilicum L. Family Lamiaceae) Assayed by Different Methodologies. Phytotherapy Research Phytother, Vol. 21, $354-361$.

6. Hussein, H., Abou-Elela, M., Amer, S. A. A., Momen, F. M. 2006. Repellency and toxicity of extracts from Capparis aegyptia to Tetranychus urticae Koch. (Acari: Tetranychidae). National Research Centre (NRC) Pests and Plant Protection Department, DokkiCairo-Egypt Acarologia, pp. 221-224.

7. Ismail, M. 2006. Anticonvulsant and hypnotic activities central properties and chemical composition of Ocimum basilicum L. essential oil. Pharmaceutical Biology, Vol. 44, pp. 619-626. https://doi.org/10.1080/13880200600897544

8. Jakienè, E. 2011. The effectiveness of the use of biological products in sugar beet crops. Žemés ūkio mokslai, Vol. 18, No. 2 , p. 65.

9. Januškevičius, A., Mikulionienè, S. Forage testing methods and feed nutrition. Kaunas. 2004. 101 p.

10. Jayasinghe, C., Goton, N., Aoki, T. 2003. Phenolics composition and antioxidant activity of sweet basil (Ocimum basilicum L.). Journal of Agricultural and Food Chemistry, Vol. 51, Iss. 15, pp. 4442-4449. https://doi.org/10.1021/jf034269o 
11. Johnny's Selected Seeds. 2015. Basil Pests and Diseases. Available at https://www.johnnyseeds.com/on/demandware.static//Library-Sites-JSSSharedLibrary/default/dw8d0e41f2/assets/information/basil-pests-diseases-tech-sheet.pdf (Accessed on 20/03/2017)

12. Keita, S. M, Vincentb, C., Schmit, J. P., Arnason, J. T., Belanger, A. 2001. Efficacy of essential oil of Ocimum basilicum L. and O. gratissimum L. applied as an insecticidal fumigant and powder to control Callosobruchus maculatus (Fab.)[Coleoptera: Bruchidae]. Journal of Stored Products Research, Vol. 37, pp. 339-349. https://doi.org/10.1016/S0022-474X(00)00034-5

13. Kruger, H, Wetzel, Sb, Zeiger B. 2002. The chemical variability of Ocimum species. J Herbs Spices Med Plants, 9, 335-44. https://doi.org/10.1300/J044v09n04_11

14. Labra, M., Miele, M., Ledda, B., Grassi, F., Mazzei, M., Sala, F. 2004. Morphological characterization, essential oil composition and DNA genotyping of Ocimum basilicum L. cultivars. Plant Science, Vol. 167, pp. $725-731$. https://doi.org/10.1016/j.plantsci.2004.04.026

15. Lee, S. J., Umano, K., Shibamoto, T., Lee, K. G. 2005. Identification of volatile components in basil (Ocimum basilicum L) and thyme leaves (Thymus vulgaris L.) and their antioxidant properties. Food Chemistry, Vol. 91, pp. 131-137. https://doi.org/10.1016/j.foodchem.2004.05.056

16. Maročkienè, N., Radzevičius, A., Karklelienè, R., Juškevičienè, D. 2012. The suitability of sweet basil (Ocimum basilicum L.) varieties for the production of fresh grass in field conditions. Sodininkyste ir daržininkystè, Vol. 35, No. (3-4), p. 68.

17. Marotti, M., Piccaglia, R., Giovanelli, E. 1996. Differences in essential oil composition of basil (Ocimum basilicum L.) Italian cultivars related to morphological characteristics. Journal of Agricultural and Food Chemistry, Vol. 44, pp. $3926-3929$. https://doi.org/10.1021/jf9601067

18. Meyers, M. 2003. Basil: An Herb Society of America Guide. The Herb Society of America, Ohio, USA.

19. Novickienè, L. 1994. Physiological bases for the development of phytohormones and retardant analogues regulating growth, development and productivity of plants. Vilnius, p. 74-83.

20. Obelevičius, K., Petkevičiūtè, S., Šeinauskienè, E. 2011. Guide for spices and their application. Kaunas, p. 127-124.

21. Ozcan, M, Chalchat, Jc. 2002. Essential oil composition of Ocimum basilicum L. and Ocimum minimum L. in Turkey. Czech Journal of Food Sciences, Vol. 20, pp. 223-228.

22. Ragažinskienė, O., Rimkienè, S., Sasnauskas, V. 2005. Encyclopedia of medicinal plants. Kaunas, 61-64. [In Lithuanian]

23. Rajesh, K. J. 2014. Chemical composition and antimicrobial activity of the essential oil of Ocimum basilicum L. (sweet basil) from Western Ghats of North West Karnataka, India. Ancient Science of Life, Vol. 33, No. 3, pp. 151-156. https://doi.org/10.4103/0257-7941.144618

24. Ruzgienè, R., Mackevičius, A. 2010. Little Vegetable and Spice Directory. Eugrimas, Vilnius, 146-204. [In Lithunian]

25. Sengul, N., Sezen, T. 2000. Chemical components of different basil (Ocimum basilicum L.) cultivars grown in Mediterranean regions in Turkey. Israel Journal of Plant Sciences, Vol. 4, Iss. 2, pp. 109-112.

26. Simon, Je., Morales, Mr., Phippen, Wb., Vieira Rf., Hao Z. 1999. Perspectives on New Crops and New Uses. Alexandria, VA: ASHS Press; A source of aroma compounds and a popular culinary and ornamental herb, pp. 499-505.

27. Tarakanovas, P., Raudonius, S. 2003. Statistical analysis of agronomic research data using computer programs ANOVA, STAT, SPILT-PLOT from SELEKCIJA and IRRISTAT from packages SELEKCIJA and IRRISTAT. Akademija, Kèdainių r.

28. Tateo, F. 1989. The composition of various oils of Ocimum basilicum L. Journal of Essential Oil, pp. 137-148.

29. Telci, I., Bayram, E., Yılmaz, G., Avc1, B. 2006. Variability in essential oil composition of Turkish basils (Ocimum basilicum L.). Biochemical Systematics and Ecology, Vol. 34, pp. 489-497. https://doi.org/10.1016/j.bse.2006.01.009

30. Tran, T. 2011. Basil Diseases. Cornell University Department of Plant Pathology and Plant-Microbe Biology. Available at http://plantclinic.cornell.edu/factsh (Accessed on 15/03/2017)

31. Vina, A, Murillo, E. 2003. Essential oil composition from twelve varieties of basil (Ocimum spp.) grown in Columbia. Journal of the Brazilian Chemical Society, Vol. 14, pp. 744-749. https://doi.org/10.1590/S0103-50532003000500008

32. Wyenandt, C.A., Simon, J.E., Pyne, R.M., Homa, K., Mcgrath, M T., Zhang, S., Madeiras, A. 2015. Basil downy mildew (Peronospora belbahrii): Discoveries and challenges relative to its control. Phytopathology, Vol. 105, Iss. 7, pp. 885-894. https://doi.org/10.1094/PHYTO-02-15-0032-FI

33. Zhang, S., Roberts, P. 2009. Florida Plant Disease Management Guide: Sweet Basil. Department of Agriculture, University of Florida, p. 113. 